\title{
MENTAL STATUS OF YOUTH DURING COVID-19: A SOCIOLOGICAL ANALYSIS
}

Jyotsna Verma, Research Scholar

Department of Arts, University of Kota, Rajasthan, India

ORCID: https://orcid.org/0000-0002-6459-4480

Email: jyv030@gmail.com

Electronic version

URL: http://www.researchambition.com

DOI: https://doi.org/10.53724/ambition/v6n2.02

ISSN: 2456-0146

Vol. 6, Issue-II, August 2021

Page No. 01 - 08

Publisher

Welfare Universe

Electronic reference/Article is to be Cited:

Jyotsna Verma, (2021). Mental Status of Youth During Covid-19: A Sociological Analysis. Research Ambition: An International Multidisciplinary e-Journal, ISSN 2456-0146, 6(II), 0108. https://doi.org/10.53724/ambition/v6n2.02

CResearch Ambition: An International Multidisciplinary e-Journal 2021. This Open Access article is published under a Creative Commons Attribution Non-Commercial 4.0 International License https://creativecommons.org/licenses/by-nc/4.0/, which permits non-commercial reuse, distribution, and reproduction in any medium, provided the original work is properly cited. For citation use the DOI. For commercial re-use, please contact editor email:- publish2017@gmail.com By accessing the work you hereby accept the Terms. Non-commercial uses of the work are permitted without any further permission from Research Ambition: An International Multidisciplinary eJournal provided the work is properly attributed.

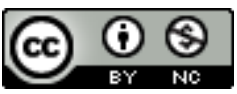

This work is licensed under a Creative Commons Attribution-NonCommercial 4.0 International License. 


\title{
MENTAL STATUS OF YOUTH DURING COVID-19: A SOCIOLOGICAL ANALYSIS
}

\author{
Jyotsna Verma, Research Scholar \\ Department of Arts, University of Kota, Rajasthan, India \\ ORCID: https://orcid.org/0000-0002-6459-4480 \\ Email: jyv030@gmail.com
}

\begin{abstract}
Happiness is a key to success. Being happy is a state of mind in the true sense when a person is mentally present at a place and sounds happy from within. It is observed that a happy person can solve many difficult problems in a couple of minutes. So, it will not be wrong to say that happiness is positivity because when a person is happy he is loaded with an enormous amount of energy which keeps him motivated. Every person passes through different stages of development; infancy, childhood, adolescence, youth, adulthood, and old age in which each stage has its own sweet as well as sour memories, but over time from infancy to childhood and then to adolescence almost everyone changes and is loaded with responsibilities. With time everything changes are its people, place, situation, society, technology, science, environment and the emergence of COVID-19 (coronavirus disease) is an infectious disease caused by a newly discovered coronavirus, has proved it to be right that people have to modify themselves with the changing situations. This COVID-19 has also proved Charles Darwin's concept the right that says "survival of the fittest", meaning a fit person will only survive and the unhealthy will be eliminated. COVID-19 being a pandemic disease have scattered everything be it people's life (emotions, state of mind, jobs, education, economic state, relationships, family, etc.), the economic crisis has occurred in overall all states, railways/airlines services have stopped, for instance, one can feel the sudden full stop to almost all the present essential services.
\end{abstract}

Keywords: Youth, society, COVID-19 (coronavirus disease).

\section{Introduction}

Coronavirus disease is caused due to a large group of viruses that cause illness in humans and animals. Mostly seen cases of coronavirus are mild but some cases are seen as very severe and can cause death. The outburst of Novel coronavirus disease COVID-19 $1{ }^{1}$ was initially noticed in a seafood market in Wuhan city in Hubei Province of China in mid-December, 2019, and has now spread throughout the world. World Health Organization (WHO) has declared this outbreak as a "Public Health Emergency of International Concern" (PHEIC) on $30^{\text {th }}$ January 2020. WHO subsequently declared COVID-19 a

\footnotetext{
${ }^{1}$ Containment Plan, Novel Coronavirus Disease 2019 (COVID 19), Version 2 (updated 16.05.2020): https://www.mohfw.gov.in/pdf/Containmentplan16052020.pdf (02.08.2021)
} 
pandemic on $11^{\text {th }}$ March 2020. Most of the people who were infected with the COVID-19 virus have mild disease and recover. Approximately $80 \%$ of laboratory-confirmed patients have had mild disease, $15 \%$ require hospitalization, and $5 \%$ cases are critical requiring ventilator management. The total number of confirmed cases is being reported from all over the world on 23rd September 2020, which is 31,375,325 including 966,399 deaths reported to the WHO. In India, the total number of cases is 5,646,010 the new case includes 83,347 and the number of confirmed deaths due to Novel coronavirus is 90,020. Current estimates the isolation period of COVID range from 2-14 days. Common symptoms include fever, fatigue, dry cough, and breathing difficulty. Upper respiratory tract symptoms like sore throat, dry cough, tiredness, chest pain or pressure, difficulty in breathing or shortness of breath, gastrointestinal symptoms like nausea/ vomiting are also reported.

We can protect ourselves from COVID-19 by-

- Cleaning hands often by using soap and water (20 seconds), or an alcohol-based hand rub.

- Maintaining a safe distance (6 feet) from a person who is coughing or sneezing

- Wearing a mask.

- Not touching eyes, nose, and mouth.

- Covering the nose and mouth with an elbow or a tissue while coughing or sneezing.

- $\quad$ Staying home.

- $\quad$ Isolating while unwell.

- If having fever, cough, and difficulty in breathing seek medical attention.

All the above points help in decreasing the number of cases that are emerging due to coronavirus and it is very possible that if everyone follows these precautions they will be contributing to the decline of this pandemic. Firstly, this is a bitter truth which is not even possible for everyone to stay at home and have patience because everyone is not fulfilled with all the necessities of life like for example daily wagers/daily earners; people who earn on daily basis are the one who has suffered the most as they do not have money even for their daily bread so they have to get out for their living. Secondly, this pandemic has guided all to maintain a social distance from each other which means that it is not safe to meet socially so it cuts one from all the social meetings which mean that one can talk and meet the other person only online (offline in very rare cases), so it as almost alienated one from the society. Thirdly, you cannot touch the other person because everyone now thinks that might be the person is infected with coronavirus or might be another person who has come in contacted with the infected person; this thought has alienated one from coming in physical touch with others. Fourth, wearing a mask or not touching your face, eyes, the nose is not easy for all because many people may be suffering from asthma, bronchitis, breathing problems, so it is impossible to carry an oxygen mask/cylinder or some may have skin problems which irritate one from using the mask. Fifth, washing hands, again and again, makes hands dry, rough, peeled off, and more prone to skin diseases and one feels like an idiot in rubbing soap or sanitizer very frequently. This COVID-19 has proved right the concept of Alienation given by Karl $\mathrm{Marx}^{2}$ to be true that alienation is detachment or isolation. So

\footnotetext{
${ }^{2}$ Alienation: Stanford Encyclopedia of Philosophy Publish on: 30 Aug. 2018 : https://plato.stanford.edu/entries/alienation/ (02.08.2021) 
basically a person is alienated from nature as all the walking parks, outdoors are closed, alienated from the group, as everyone is locked behind the home doors and doing their office, works from home, students attending online classes, high unemployment, prolonged global recession, weakening of major economies, alienated from the self as staying home for all day has made one get bored and frustrated and alienation from the society as it is difficult to contact face-to-face as everyone has to maintain a distance from each other which in turn has increased virtual meetings and lowered social meetings. This detachment is increasing aloofness, frustration, insecurity, blocked, stressed, bounded, boredom which is triggering oneself and directing them towards the wrong path. This pandemic time of COVID19 has given everybody a chance to live again as people used to miss the holidays of home, they do not have time to spend it with their family members and children, all of us got so much engaged in our work, be it household chores from morning to evening or be it office jobs of 9:00 am-5:00 pm, be it classes of students, or time which we all spend on social media, traveling, etc. Every single day to day activity is affected by a coronavirus which is becoming a major changing factor in everyone's life.

\section{Purpose of the Research}

The objective of this study is to know the stress level in youth due to the pandemic situation created by Novel coronavirus (COVID-19). The study is done to find out the problems which a youth is facing during this period. This theme will surely help get the required results and solve the purpose of the study.

\section{Importance of the Research}

In today's scenario, the world is completely shattered from the effects of COVID-19, and everyone is under fear and pressure of many unknown factors like economy, health, wealth, environment, societal and technological; so this study may be significant in finding out the real factors which are forcing youth towards the wrong path and taking the society towards risk as the youth are the major part of the building blocks of the Nation.

\section{Some of the case studies due to coronavirus are underlined below}

A study says that COVID-19 has shaken the mental balance of people where $32 \%$ are suffering from depression and $40 \%$ have sleeping-related issues. This is because there is a sudden cut-off of social contacts and face-to-face meetings. Dr. Mohsin Vali of Sir Gangaram Hospital in New Delhi says experts of San Reifel hospital have written surprising things related to research in an Italian magazine. Expert says, in the upcoming days, 30-32\% of people may have depression, $40 \%$ restlessness, and $40 \%$ of people may lack sleep. Besides, $20 \%$ of people may have an obsession with compliance disorders. All this is happening in different ways in patients, during Covid-19. According to Dr. Mohsin Wali, people recovering from corona show body pain, stiffness, and lethargy for the next 3-4 months. There are some people whose mental state is changing, such as sudden calm down, or not talking to anyone. Anamika Papadiwal, a psychologist says that parents should spend some time with children; as they should play with them, hear and narrate stories to them; the same way as we all used to listen from our grandparents. Children want to talk with their parents but they are unable to speak as parents are busy. Parents have to keep their children busy with activities like indoor games, painting, or some brain games. As everyone is stressed out because of the coronavirus so do children also get irritated, get upset, or gets up angry very easily. So, parents should spend more time with their children and have to listen and question them, love them, and teach them how to be calm. 
According to Dr. Soumitra Pathare, says that in the starting first week of lockdown people were separated from alcohol as there was a shut down in the market. In the second, the third, and fourth week of the lockdown people were afraid of getting COVID-19, or they felt that they are already affected by a coronavirus, or they are being boycotted by the neighbours even when they didn't have it. And in the last ten days, there are stories of suicide where the reasons are the lack of food or money or employment or worries about employment. So, from a sociological perspective, this study agrees with the pathological division of labour a concept given by Emile Durkheim; ${ }^{3}$ where he confines that the imbalance created in the society will always lead towards problems which in turn give rise to frustration, anger, stress, aggression, negativity and ultimately suicide.

Kerala, a 15-year-old girl in Class X committed suicide because she was unable to attend online classes because she did not have access to a smartphone; her father was a day labourer but because of COVID-19 and lockdown he has not earned enough money. The reason student committed suicide is that she thought her academic performance would be greatly affected because she had missed class lessons due to this she was depressed and committed suicide.

\section{Research Methods}

Research scholar has chosen Kota city as an area of research and will be taken 30 respondents (both male and female) with the age group of 15-24 years; assimilating ten questions (open and closedended) related to the topic which will surely help in finding the actual problems faced by the youth. The data collection will be done through a convenience sampling method with all primary sources using a questionnaire method.

Table no.1

\begin{tabular}{|c|c|c|c|c|}
\hline $\begin{array}{c}\text { Do you think coronavirus has } \\
\text { worsened the situation of youth } \\
\text { in regards to Employment? }\end{array}$ & \multicolumn{2}{|c|}{ Respondents } & Total & Percentage \\
\hline & Male & Female & & \\
\hline Yes & 15 & 15 & 30 & 100 \\
\hline No & 0 & 0 & 0 & 0 \\
\hline Total & 15 & 15 & 30 & 100 \\
\hline
\end{tabular}

It is very true that due to COVID-19, many youths are facing employment problems which are surely affecting them negatively. They are going through a tough recession in which they are forcefully expelled out of the job in some cases they have to do work for long hours and in turn, they are paid half of their salary which is also not on time, and because of this they are in mental pressure as to how they will fulfill the necessities of the life and they are also affected physically as long sitting hours for work has made their body stiff and painful (eyes, hands, neck, shoulder) which makes them angry, bored, and frustrated very easily.

Table no.2

\begin{tabular}{|c|r|r|r|r|}
\hline $\begin{array}{l}\text { Is the Government taking } \\
\text { measurable steps for the cure of } \\
\text { corona patients? }\end{array}$ & \multicolumn{2}{l|}{ Respondents } & Percentage \\
\hline & Male & Female & & 76.67 \\
\hline Yes & 10 & 13 & 23 & 23.33 \\
\hline No & 5 & 2 & 7 & 100 \\
\hline Total & 15 & 15 & 30 & \\
\hline
\end{tabular}

\footnotetext{
${ }^{3}$ What is suicide: https://durkheim.uchicago.edu/Summaries/suicide.html $(02.08 .2021)$
} 
Concerning the table, many respondents have accepted that yes the government is not taking the effective steps needed to fight back the COVID-19 pandemic because as seen around that also after imposing section 144; many people are seen to be gathering at a place without any reason and the police force was also not so much consideration for it. Also seen in some cases that many hospitals are not sanitized properly and people also have to suffer for the basic requirements needed. A clear fact, seen during this COVID-19, is that the ratio of patients is much more as compared to the Doctors needed for the treatment; as while treatment doctors are also coming in contact with this coronavirus.

Table no.3

\begin{tabular}{|c|c|c|c|c|}
\hline \multirow{2}{*}{$\begin{array}{l}\text { How technology is playing a } \\
\text { vital role in COVID-19 }\end{array}$} & \multicolumn{2}{|c|}{ Respondents } & \multirow[t]{2}{*}{ Total } & \multirow[t]{2}{*}{ Percentage } \\
\hline & Male & Female & & \\
\hline Work from home & 4 & 5 & 9 & 30 \\
\hline Delivery of essential services & 3 & 3 & 6 & 20 \\
\hline Online payments & 4 & 3 & 7 & 23 \\
\hline Online medical services & 2 & 2 & 4 & 13 \\
\hline Use of TV, Internet, Mobile & 2 & 1 & 3 & 10 \\
\hline Use of Aarogya Setu App & 0 & 1 & 1 & 3 \\
\hline Total & 15 & 15 & 30 & 100 \\
\hline
\end{tabular}

Technology is playing a very helpful role during the corona situation; in medical services medicines can be ordered using particular medical apps, online payments and transitions are helpful for all, Aarogya Setu App limits us while coming in contact with the corona person, now classroom studies are done with the help of online classes, and working from home are also. With the help of technology, people can read newspapers through their apps, or anyone can excel in their business with technology as going out is limited.

Table no.4

\begin{tabular}{|c|c|c|c|c|}
\hline $\begin{array}{c}\text { Does COVID-19 is the main } \\
\text { reason for the increased rate of } \\
\text { suicide in the state? }\end{array}$ & \multicolumn{2}{|c|}{ Respondents } & Total & Percentage \\
\hline Yes & Male & Female & & \\
\hline No & 4 & 2 & 6 & 20 \\
\hline Total & 11 & 13 & 24 & 80 \\
\hline & 15 & 15 & 30 & 100 \\
\hline
\end{tabular}

Many of the respondents are in the view that coronavirus is not the only factor for the increase in suicide rate but there are other problems like mental illness, aggressive behaviour, lack of moral and social support, family disruptions, etc.

Table no.5

\begin{tabular}{|c|c|c|c|c|}
\hline $\begin{array}{c}\text { Can coronavirus be } \\
\text { stopped by maintaining a } \\
\text { complete lockdown? }\end{array}$ & \multicolumn{2}{|c|}{ Respondents } & Total & Percentage \\
\hline Mes & Male & Female & & \\
\hline No & 10 & 12 & 22 & 73 \\
\hline Total & 5 & 3 & 8 & 27 \\
\hline
\end{tabular}


Taking precautions, making a social distance, hand sanitization, wearing a mask is an effective way in a coronavirus cure, and if possible a complete lockdown will be very helpful in decreasing the number of cases in the state.

Table no.6

\begin{tabular}{|l|r|r|r|r|}
\hline $\begin{array}{l}\text { How much we are responsible } \\
\text { for the increasing rate of the } \\
\text { coronavirus? }\end{array}$ & \multicolumn{2}{|c|}{ Respondents } & Total & Percentage \\
\hline & Male & Female & & \\
\hline Environment Cleanliness & 1 & 0 & 1 & 3 \\
\hline No proper Hygiene/Sanitization & 5 & 6 & 11 & 36.66 \\
\hline No Social Distancing & 4 & 6 & 10 & 33.33 \\
\hline Less use of face mask & 4 & 3 & 7 & 23.33 \\
\hline $\begin{array}{l}\text { Less distribution of necessities to } \\
\text { needed people }\end{array}$ & 1 & 0 & 1 & 3 \\
\hline \multicolumn{1}{|c|}{ Total } & 15 & 15 & 30 & 100 \\
\hline
\end{tabular}

If everyone is well aware of the proper hygiene which has to be maintained in this pandemic situation then surely everyone can strongly fight against this virus.

Table no.7

\begin{tabular}{|c|r|r|r|r|}
\hline $\begin{array}{l}\text { Do youths feel more depressed } \\
\text { than being happy in the current } \\
\text { scenario? }\end{array}$ & \multicolumn{2}{|c|}{ Respondents } & Total & Percentage \\
\hline & Male & Female & & \\
\hline Yes & 13 & 15 & 28 & 93.3 \\
\hline No & 2 & 0 & 2 & 6.66 \\
\hline Total & 15 & 15 & 30 & 100 \\
\hline
\end{tabular}

Yes, youths are more depressed than before because they are bounded in homes for months, they are not getting jobs after getting degrees; they feel lonely, lost touch of friends and near ones.

Table no.8

\begin{tabular}{|c|r|r|r|r|}
\hline $\begin{array}{l}\text { Is it possible for everyone to } \\
\text { become self-employed after a } \\
\text { sudden recession? }\end{array}$ & \multicolumn{2}{|c|}{ Respondents } & Total & Percentage \\
\hline & Male & Female & & \\
\hline Yes & 2 & 1 & 3 & 10 \\
\hline No & 13 & 14 & 27 & 90 \\
\hline Total & 15 & 15 & 30 & 100 \\
\hline
\end{tabular}

Self-employment is based on skill factors that are less developed in everyone and it is not an easy task for people to stand up for their business as everyone is going through economic crises and the pandemic situations are making things worse.

Table no.9

\begin{tabular}{|c|c|c|c|c|}
\hline $\begin{array}{c}\text { Do technology helps manage stress } \\
\text { level in youth during a lockdown? }\end{array}$ & \multicolumn{2}{|c|}{ Respondents } & Total & Percentage \\
\hline & Male & Female & & \\
\hline Yes & 9 & 10 & 19 & 63.33 \\
\hline No & 6 & 5 & 11 & 36.66 \\
\hline Total & 15 & 15 & 30 & 100 \\
\hline
\end{tabular}


Technology is used to share information, pictures, videos, links, etc. in this corona situation people have some time which they share with their loved ones and get connected with them online through video calls, chats, voice notes this helps them giving the feel of being in touch.

Table no.10

\begin{tabular}{|c|c|c|c|c|}
\hline $\begin{array}{c}\text { Do the COVID-19, situation } \\
\text { taking youth in the wrong } \\
\text { direction for earning a } \\
\text { livelihood? }\end{array}$ & \multicolumn{2}{|c|}{ Respondents } & Total & Percentage \\
\hline Yes & Male & Female & & \\
\hline No & 11 & 9 & 20 & 66.66 \\
\hline Total & 4 & 6 & 10 & 33.33 \\
\hline
\end{tabular}

If seen around everyone is living in fear; a threat of being murdered, getting raped, domestic violence, getting kidnapped, cyber-crimes, petty crimes, robbery, etc., these crimes are increasing because youths have dreams of high living but they do not have enough money and the COVID-19, time is a time where everyone is running for the basic needs of life.

\section{Conclusions}

This discussion on the impact of coronavirus on youth has lead us to find out that what are the psychological challenges youth are coming across and how they can be fulfilled. From the findings, it is clear that youths are facing difficulty in life and these situations have to be tackled with proper guidance and support through parents and guardians. Youths are dealing with tough competition to manage their ongoing jobs or in finding a job; the organizations should make sure with their employees that they will not be expelled from the organization without any reason. In this regard, the government should come forward with new planning and assist and ensure people that they are their responsibilities too; and they are with them in every situation of life. In this pandemic time, everyone needs someone to listen to them so nobody can deal with alienation and counsel them towards the right path so they can get focused on their interests and work and this can help decrease the number of crimes. 